\title{
Effects on pregnancy in mice of passive immunization against ovine LH and human chorionic gonadotrophin*
}

\author{
A. Tandon $\dagger$, C. Das, B. L. Jailkhani, Amitabh Gaur, S. Sehgal $\ddagger$, \\ G. Gopinath $\S$ and G. P. Talwar
}

Departments of Biochemistry and §Anatomy, All India Institute of Medical Sciences \& National Institute of Immunology, New Delhi-110029, and $\ddagger$ Post-Graduate Institute of Medical Education and Research, Chandigarh-160012, India

\begin{abstract}
Summary. Mice given daily i.p. injections of immunoglobulins against ovine LH on Days 3-7 of pregnancy were devoid of implantation sites on Day 8 whereas mice treated with antibodies to hCG had embryos of normal number and appearance on Day 8. These antibody treatments reduced the mean \pm s.d. serum progesterone concentrations from $65.4 \pm 15.3 \mathrm{ng} / \mathrm{ml}$ (control globulins) to $8.6 \pm 4.9 \mathrm{ng} / \mathrm{ml}$ (anti-LH) and $9 \cdot 2 \pm 3 \cdot 1 \mathrm{ng} / \mathrm{ml}$ (anti-hCG) on Day 8 and had no differential effect on serum oestrogen levels on Day 4. However, the mice treated with anti-hCG did not litter; resorption of the embryos took place between Days 10 and 14 of pregnancy.

Indirect immunofluorescence and quantitative immunoenzymic assays showed the presence of anti-ovine LH and anti-hCG reacting antigens in the mouse feto-placental unit. On Day 6, the values of reacting antigens (mean \pm s.d. absorbance units $/ 10 \mu \mathrm{m}$ section of embryo) were $0.050 \pm 0.002$ with control globulins, $0.059 \pm 0.002$ with antihCG-Ig and $0.196 \pm 0.018$ with anti-LH-Ig; the corresponding values on Day 12 were $0.075 \pm 0.009,0.402 \pm 0.02$ and $0.416 \pm 0.015$. The quantitative disposition of the reacting antigens to the two types of anti-gonadotrophins seems to bear a temporal relationship to their respective antifertility action.

The pregnancy terminating action of immunoglobulins to ovine LH (Days 6, 7 \& 8) and hCG (Days 8, $9 \& 10$ ) was counteracted by administration of $2 \mathrm{mg}$ medroxyprogesterone acetate on Days 6,9 and 12, indicating the importance of progesterone in the maintenance of pregnancy in the mouse.
\end{abstract}

\section{Introduction}

Immunization against $\mathrm{LH}$ or chorionic gonadotrophin (CG) is able to terminate early pregnancy in a variety of animals (mouse: Munshi, Purandare \& Rao, 1972; rat: Loewit \& Laurence, 1969; Madhwa Raj \& Moudgal, 1970; Bambra \& Gombe, 1978; hamster: Rao, Madhwa Raj \& Moudgal, 1972; rabbit: Spies \& Quadri, 1967; bonnet monkey: Prahalada, Mukku, Rao \& Moudgal, 1975; Moudgal, Mukku, Prahalada, Murty \& Li, 1978; marmoset: Hearn, Short \& Lunn, 1979; baboon: Stevens, 1976; Tandon, Das, Jailkhani \& Talwar, 1981). The mechanism by which such immunization causes abortion is not fully understood. The antibodies could abrogate the gonadotrophin-induced rescue of the corpus luteum. The rise of serum progesterone during the

\footnotetext{
* Reprint requests to Professor G. P. Talwar, National Institute of Immunology, New Delhi-1 10029, India.

$\dagger$ Present address: Department of Obstetrics \& Gynaecology, Hyogo Medical College, Nishinomiya, Hyogo 663, Japan.
} 
second part of the luteal cycle is temporally related to the appearance of CG in man (Yoshimi, Strott, Marshall \& Lipsett, 1969) and other primates (Knobil, 1973) and stimulation of progesterone production by the corpus luteum by CG is demonstrable in vivo (Garner \& Armstrong, 1977 ) and in vitro (Rice, Hammerstein \& Savard, 1964). The antigonadotrophin may also have an action locally at the implantation site. Immunoreactive hCG-like material is detectable along the trophoblast lining in villi (Midgley \& Pierce, 1962; Paul, Jailkhani, Gupta \& Talwar, 1979) and it has been suggested that lining by a 'self' immunologically tolerated protein provides protection to the feto-placental unit against immunological rejection (Borland, Loke \& Wilson, 1975). The experiments reported in this paper evaluate the contributory role of these factors in mice immunized against gonadotrophins. Antibodies against a widely cross-reacting gonadotrophin, ovine LH, as well as hCG which has a narrower specificity were employed. We used mice as the experimental animals because of the reported presence of a CG-like material in implantation sites and placentae from Day 5 until Day 19 of gestation (Wide \& Wide, 1979).

\section{Materials and Methods}

Antibodies. Purified hCG (biological activity: 12000 i.u./mg, provided by the Population Council, New York, U.S.A.) or ovine LH (NIH-LH-S17) was dissolved (100 $\mu \mathrm{g}$ of each) in sterile saline ( 8.5 $\mathrm{g} \mathrm{NaCl} / \mathrm{l}$ ) and emulsified with an equal volume of Freund's complete adjuvant (Difco Laboratories, Detroit, MI, U.S.A.). The emulsion was injected intradermally at multiple sites on the shaven backs of rhesus monkeys: 6 monkeys ( 3 for each hormone) were immunized. Booster injections of $50 \mu \mathrm{g} \mathrm{hCG}$ (or ovine LH) emulsified with incomplete Freund's adjuvant (Difco) were given at 4 intramuscular sites every 4 weeks. Two monkeys were injected intradermally with Freund's complete adjuvant alone (without antigen) and were given Freund's incomplete adjuvant intramuscularly to serve as donors of control sera. Control and immunized monkeys were bled every 14 days by saphenous venepuncture. Sera were stored at $4^{\circ} \mathrm{C}$ with $0.1 \%$ sodium azide as preservative. Sera having a binding capacity for ${ }^{125} \mathrm{I}$-labelled hCG of more than $40-50 \%$ at $1: 1000$ dilution in a radioimmunoassay system (Shastri, Dubey, Vijaya Raghavan, Salahuddin \& Talwar, 1978 ) using ethanol :ammonium acetate (final concentrations, 6.6\% ammonium acetate and $66 \%$ alcohol) instead of second antibody were pooled. Immunoglobulins ( $\mathrm{Ig}$ ) were precipitated from pooled immune or control serum at $50 \%$ ammonium sulphate saturation, dissolved in $10 \mathrm{~mm}$ phosphate-buffered saline (PBS), $\mathrm{pH} 7 \cdot 4$, and dialysed against PBS for $72 \mathrm{~h}$ with 6 changes of PBS. The dissolved dialysed globulins were centrifuged at $12000 \mathrm{~g}$ for $45 \mathrm{~min}$ to remove suspended undissolved particles and the solution was passed through a Millipore disc $(0.22 \mu \mathrm{m}$ pore size $)$ under sterile conditions.

The hCG-neutralizing ability of the antibodies was determined by the mouse Leydig cell assay (having a sensitivity of $15 \mu \mathrm{i} . \mathrm{u}$. hCG), supplemented by the weight gain assays for the mouse uterus and rat prostate gland (Das, Salahuddin \& Talwar, 1976; Das et al., 1978).

Mouse pituitary gonadotrophin. Pituitaries from adult mice of the Swiss strain were suspended (10 mg wet weight $/ \mathrm{ml}$ ) in phosphate-buffered saline (containing $6.5 \mathrm{~mm}-\mathrm{Na}_{2} \mathrm{HPO}_{4} .2 \mathrm{H}_{2} \mathrm{O}, 1.4 \mathrm{~mm}$ $\mathrm{KH}_{2} \mathrm{PO}_{4}, 135 \mathrm{mM}-\mathrm{NaCl}$ and $0 \cdot 1 \% \mathrm{BSA}$ ) $\mathrm{pH} 7.4$ and sonicated at $20000 \mathrm{~Hz}$ for $15 \mathrm{~min}$. The sonicate was centrifuged at $20000 \mathrm{~g}$ for $45 \mathrm{~min}$ at $4^{\circ} \mathrm{C}$. The supernatant was tested in the mouse Leydig cell assay (Das et al., 1978) for gonadotrophic activity. The ability of immunoglobulins to ovine LH and hCG to neutralize mouse pituitary gonadotrophic activity was checked in the same bioassay system. Pituitary extract and antibodies were incubated at $37^{\circ} \mathrm{C}$ for $2 \mathrm{~h}$ and then at $4^{\circ} \mathrm{C}$ overnight, after which the mouse Leydig cells were added to this mixture and the testosterone produced was measured by radioimmunoassay. The antiserum (S-741 No. 7) used in this assay was obtained from Dr G. A. Abraham, California. Labelled testosterone (tritium at four places) was purchased from New England Nuclear (Boston, MA, U.S.A.).

Animals. Cyclic female mice of the Swiss and NMRI strains, randomly bred at AIIMS and 
weighing $25-30 \mathrm{~g}$, were used. A total of 80 mice was taken for the study and females were caged in groups of 3 with a male of proven fertility. The day of finding a vaginal plug was taken as Day 1 of pregnancy. Mice were killed by cervical dislocation at different stages of pregnancy. Uterine horns with embryonic implantation sites were frozen at $-70^{\circ} \mathrm{C}$ and stored until required.

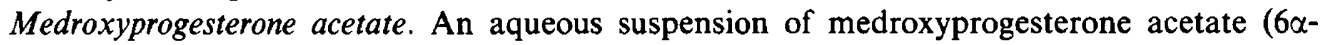
methyl-17 $\alpha$-hydroxy-pregn-4-ene-3,20-dione acetate), supplied by Upjohn Company, Kalamazoo, MI, U.S.A. as Depo-Provera, was emulsified with ground-nut oil. In mice, the dose of MPA required for pregnancy maintenance after removal of ovaries on Day 6 of pregnancy was determined. The MPA emulsion was injected intramuscularly on Days 6, 9 and 12 of pregnancy.

Steroid assays. Serum progesterone/oestradiol concentrations were measured by a competitive protein-binding method as described by Aso, Guerreo, Cekan \& Diczfalusy (1975). The antisera were supplied by the WHO Programme for the Provision of Matched Assay Reagents for the Radioimmunoassay of Hormones in Reproductive Physiology. The specificity of the progesterone antiserum was expressed by its cross-reactions at $50 \%$ binding as follows: $5 \alpha$-dihydroprogesterone $(7 \%), 20 \alpha$-dihydroprogesterone $(<3 \%), 17 \alpha$-hydroxyprogesterone $(<3 \%)$, testosterone $(<0.2 \%)$, and cortisol $(<0.01 \%)$. The specificity of the oestradiol antiserum was expressed by its crossreactions at $50 \%$ binding as follows: oestrone $(1.7 \%)$, testosterone $(<0.0002 \%)$ and cortisol $(<0.0001 \%)$.

Due to the high specificity of the antisera used, it was possible to perform the radioimmunoassay directly on the ether extracts of serum without employing chromatographic purification of the steroids. Samples for the progesterone assay $(0.1 \mathrm{ml})$ were extracted with a $20-$ fold volume of anhydrous diethyl ether by vortexing for $1 \mathrm{~min}$. The aqueous layer was frozen in an ethanol : solid $\mathrm{CO}_{2}$ mixture and the ether solution was decanted into a test tube. The residue, obtained after the evaporation of ether at room temperature overnight, was dissolved in $0.2 \mathrm{ml}$ gelatin-phosphate-buffered saline, $0.01 \mathrm{M}, \mathrm{pH} 7.4$ (containing $0.1 \%$ sodium azide) by heating the mixture in a $60^{\circ} \mathrm{C}$ water bath for $10 \mathrm{~min}$ and vortexing for $15 \mathrm{sec}$.

The aqueous extract $(0.2 \mathrm{ml})$ was combined with a $0.1 \mathrm{ml}$ mixture of equal volumes of appropriately diluted antiserum $(\mathrm{Bo}=40 \%)$ and radioactive progesterone/oestradiol solution. The resulting solution $(0.3 \mathrm{ml})$ was incubated for $10 \mathrm{~min}$ at $60^{\circ} \mathrm{C}$, followed by $18 \mathrm{~h}$ at $4^{\circ} \mathrm{C}$ for separating the bound and unbound fractions. Then $0.5 \mathrm{ml}$ chilled $1 \%$ charcoal prepared in gelatin-phosphatebuffered saline was added to the tubes. After keeping in an ice bath for $15 \mathrm{~min}$, the tubes were centrifuged at $1000 \mathrm{~g}$ for $5 \mathrm{~min}$. The charcoal supernatant was decanted in a scintillation vial containing $1 \mathrm{ml}$ double-distilled ethyl alcohol. After putting $10 \mathrm{ml}$ scintillation fluid $(0.4 \%$ PPO and $0.05 \%$ POPOP in toluene) in each vial, the radioactivity of the bound fraction was counted in Packard Scintillation Spectrometer. The non-specific binding was $2-4 \%$. For the progesterone assay, the limit of sensitivity was $12.5 \mathrm{pg}$ with the standard ranging from 12.5 to $400 \mathrm{pg} /$ assay tube. For the oestradiol assay the limit of sensitivity was $6.25 \mathrm{pg}$ with the standard ranging from $6.25 \mathrm{pg}$ to $400 \mathrm{pg} /$ assay tube. The inter- and intra-assay coefficients of variation were in the range of $10-$ $12 \%$ and $4-6 \%$ respectively for these steroids.

Immunofluorescence test. Uterine horns with embryos kept at $-70^{\circ} \mathrm{C}$ were brought to $-20^{\circ} \mathrm{C}$ and embedded in OCT compound (Lab. Tek. Products, Naperville, IL, U.S.A.). They were sectioned longitudinally at $10 \mu \mathrm{m}$ in a cryostat set at $-20^{\circ} \mathrm{C}$. The sections were mounted on a microscope slide and stored at $-20^{\circ} \mathrm{C}$ overnight. Storage prevented the loss of sections during subsequent washing operations. The slides were brought to room temperature and the sections of implantations were allowed to react with immunoglobulins to hCG or to ovine LH for $30 \mathrm{~min}$ at $37^{\circ} \mathrm{C}$ in a humid chamber. Embryos at the same stage of development were also independently treated with control monkey globulins. After $30 \mathrm{~min}$, unbound globulins were washed off with 50

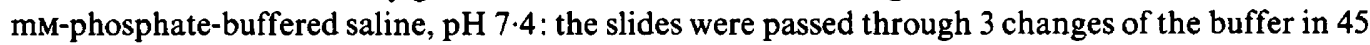
min. Implantation sites were subsequently treated with a $1: 16$ dilution of fluorescein conjugated with antihuman immunoglobulin (Burroughs Wellcome Laboratories, Beckenham, Kent, U.K.) for $30 \mathrm{~min}$. Excess of conjugate was washed off, as described above, in PBS for $45 \mathrm{~min}$. The slides 
were mounted in $5 \%$ glycerol in PBS and viewed under a Reichert u.v. microscope using exciter filter $\mathrm{E}_{1}$ and barrier filter $\mathrm{SP}_{3}$. Stained sections could be stored at $4^{\circ} \mathrm{C}$ for 2-3 weeks without any loss of intensity.

Immunoenzymic test. Longitudinal sections $(10 \mu \mathrm{m})$ of mouse embryos at two developmental stages (Days 6 and 12) were exposed to control monkey globulins or to anti hCG/ovine LH immunoglobulins at $1: 50$ dilution in PBS for $60 \mathrm{~min}$ at $37^{\circ} \mathrm{C}$. The sections were then washed by immersing in PBS for 45 min with 3 changes of the buffer at $37^{\circ} \mathrm{C}$. Endogenous peroxidase activity was blocked by dipping the slides in methanol containing $0.3 \%$ hydrogen peroxide for 30 min at room temperature. Methanol was removed by washing in PBS with 3 changes of buffer over a period of $45 \mathrm{~min}$. The sections were then treated with Protein A tagged with horseradish peroxidase (Sigma Type VI) at $1: 200$ dilution in PBS for $60 \mathrm{~min}$ at $37^{\circ} \mathrm{C}$, and washed in PBS for 45 min with 3 changes of the buffer. The embryo sections were then dissolved in $1 \mathrm{ml}$ citrate-phosphate buffer, $200 \mathrm{~mm}$, pH $5 \cdot 5$, containing $0 \cdot 1 \%$ Triton X-100 and collected in a tube. Citrate-phosphate buffer (1 ml) containing ortho-phenylenediamine $(2 \mathrm{mg} / \mathrm{ml})$ and $\mathrm{H}_{2} \mathrm{O}_{2}(0 \cdot 12 \%)$ was added to all tubes and allowed to react in the dark for $15 \mathrm{~min}$. The enzyme action was stopped by adding $0.2 \mathrm{ml} 5 \mathrm{~N}$ $\mathrm{H}_{2} \mathrm{SO}_{4}$. The colour density was read at $492 \mathrm{~nm}$ in a Pye Unicam SP8-100 spectrophotometer. The absorbance obtained was then divided by the number of embryos present in the section.

\section{Results}

\section{Effects on pregnancy of immunization against $L H$ and $h C G$}

Pregnant mice were injected intraperitoneally with the immunoglobulin fraction of the antisera to ovine LH or hCG or to control globulins daily between Day 3 and 7 of pregnancy (Table 1). Laparotomy on Day 8 showed that most of the mice treated with antibodies to LH had no implantation sites. Two of the mice in this group had resorbing embryos. To check whether the lack of implantation sites was due to failure to ovulate, the experiment was repeated but with a unilateral laparotomy, under ether anaesthesia, on Day 3 of pregnancy. The ovaries were examined for ovulation points and then the mice were treated with antibodies to $\mathrm{LH}$ as before. The 5 mice treated with $50 \mathrm{mg}$ control globulins $/ 0.5 \mathrm{ml}$ PBS had $3.9 \pm 2.8$ (s.d.) ovulations on the right ovary on Day 3 and $6.9 \pm 1.8$ embryos in the uterine horns on Day 8 . In the 7 anti-LH-treated mice ( $47 \mathrm{mg}$ $\mathrm{Ig} / 0.5 \mathrm{ml}$ ) there were $4.1 \pm 2.1$ ovulations on Day 3 but no implantations in 6 of the mice and 7 resorbed embryos in the other mouse on Day 8.

Table 1. Effect of immunoglobulins (Ig) against ovine LH and hCG on implantation sites on Day 8 of pregnancy in mice

\begin{tabular}{|c|c|c|c|}
\hline Group & Treatment* & $\begin{array}{l}\text { No. of } \\
\text { mice }\end{array}$ & $\begin{array}{c}\text { Implantation sites } \\
\text { on Day } 8 \\
\text { (mean } \pm \text { s.d.) }\end{array}$ \\
\hline I & $\begin{array}{l}\text { Control monkey globulins } \\
\text { (injected with Freund's } \\
\text { complete adjuvant alone) } \\
\text { (50 mg Ig/0.5 ml) }\end{array}$ & 7 & $8 \cdot 8 \pm 1 \cdot 8$ \\
\hline II (a) & $\begin{array}{l}\text { Monkey anti-oLH Ig } \\
(47 \mathrm{mg} \mathrm{Ig} / 0.5 \mathrm{ml})\end{array}$ & 12 & $\begin{array}{l}0 \text { in } 10 \text { mice } \\
7 \cdot 9 \pm 1 \cdot 0 \text { resorbing } \\
\text { in } 2 \text { mice }\end{array}$ \\
\hline II (b) & $\begin{array}{l}\text { Monkey anti-oLH Ig } \\
\text { diluted } 500 \text { times } \\
(94 \mu \mathrm{g} / 0.5 \mathrm{ml})\end{array}$ & 8 & $\begin{array}{l}0 \text { in } 7 \text { mice } \\
8 \text { resorbing in } \\
1 \text { mouse }\end{array}$ \\
\hline III & $\begin{array}{l}\text { Monkey anti-hCG Ig } \\
(45 \mathrm{mg} / 0.5 \mathrm{ml})\end{array}$ & 9 & $8 \cdot 4 \pm 2 \cdot 1$ \\
\hline
\end{tabular}

* Globulins equal to the amount indicated were injected i.p. daily on Days 3-7. 
Treatment with antibodies to hCG had no effect on the number and gross appearance of embryos on Day 8 of pregnancy (Table 1). The globulin preparation used was able to bind hCG, as determined by radioimmunoassay, with a titre of $13 \mu \mathrm{g} \mathrm{hCG} / \mathrm{ml}$ and was also effective in neutralizing the activity of hCG in the mouse Leydig cell, mouse uterine weight and rat ventral prostate weight gain assays.

\section{Reactivity of antibodies to ovine $L H$ and $h C G$ with mouse pituitary gonadotrophin}

The two types of immunoglobulins were examined for reaction with mouse pituitary extract in the mouse Leydig cell assay. The results in Text-fig. 1 show neutralization of the effect of the pituitary gonadotrophin by the anti-LH and anti-hCG immunoglobulins. However, the antibodies against ovine $\mathrm{LH}$ were about 500 times more potent than those against hCG. Another set of experiments was therefore performed using immunoglobulins against ovine LH diluted 500 times. This preparation had the same effect as was obtained with greater amounts of antibodies.

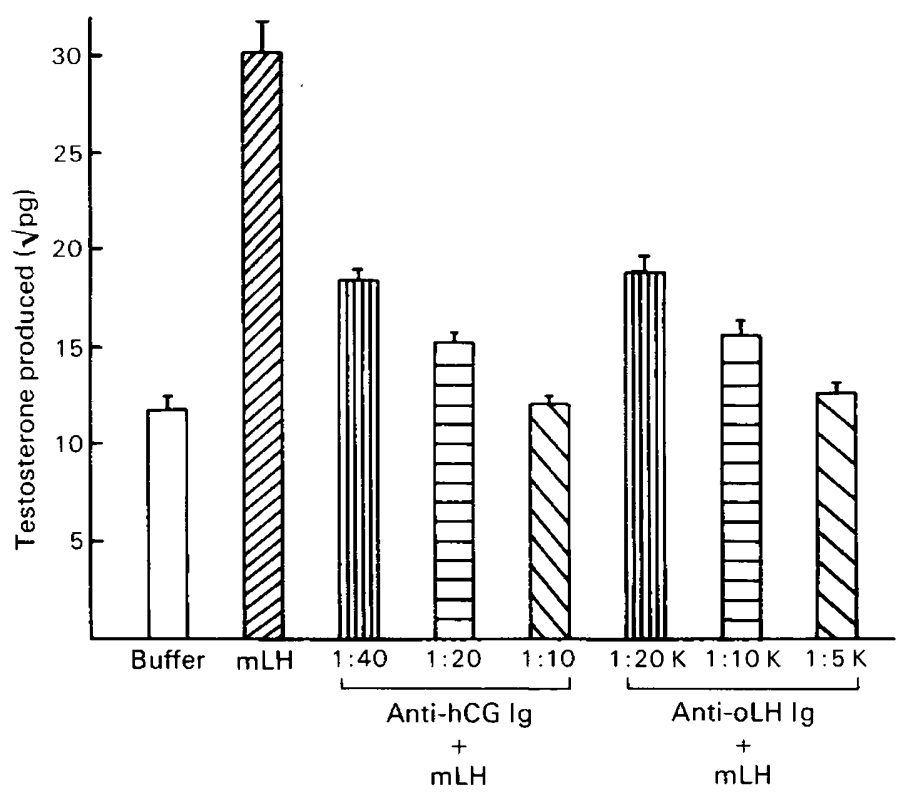

Text-fig. 1. Action of immunoglobulins (Ig) against ovine LH or hCG on the mouse pituitary extract-induced rise in testosterone production by mouse Leydig cells. See 'Materials and Methods' for experimental details. The antibodies were tested at three dilutions. $\mathrm{K}$ is equal to 1000 . Values are mean \pm s.d. for triplicate determinations.

Effect of antibody treatment on sex steroid levels

Serum progesterone levels were measured on Day 8 of pregnancy in mice treated with immunoglobulins against $\mathrm{LH}$ and hCG. The progesterone concentrations in the antibody-treated mice were of the same order and substantially lower than those in mice receiving control globulins (Table 2).

However, the serum oestradiol concentrations on Day 4 of pregnancy, i.e. around the day of implantation, were not affected (Table 2). 
Table 2. Effect of administration of immunoglobulins (Ig) against ovine $\mathrm{LH}$ and hCG on Days 3-7 on serum progesterone and oestradiol levels in pregnant mice

\begin{tabular}{|c|c|c|c|}
\hline Group & Treatment & $\begin{array}{c}\text { Progesterone } \\
\text { conc. on Day } 8 \\
\text { (ng/ml) }\end{array}$ & $\begin{array}{c}\text { Oestradiol } \\
\text { conc. on Day } 4 \\
(\mathrm{pg} / \mathrm{ml})\end{array}$ \\
\hline I & $\begin{array}{l}\text { Control monkey } \\
\text { globulins }\end{array}$ & $65 \cdot 4 \pm 15 \cdot 3(6)$ & $31 \cdot 6 \pm 2 \cdot 3(6)$ \\
\hline II & Monkey anti-oLH Ig & $8 \cdot 6 \pm 4 \cdot 9(12)$ & $29 \cdot 8 \pm 1 \cdot 4(6)$ \\
\hline III & Monkey anti-hCG Ig & $9 \cdot 2 \pm 3 \cdot 1(7)$ & $32 \cdot 5 \pm 1 \cdot 7(6)$ \\
\hline
\end{tabular}

Values are mean \pm s.d. for the no. of mice in parentheses.

\section{Delayed action of anti-hCG immunoglobulins}

Some of the animals treated with antibodies to hCG were allowed to go to term so that the normality of the progeny could be assessed. However, no young were born. Laparotomy on Day 22 of pregnancy revealed the presence of embryonic sites. Similarly treated mice were then laparotomized on Days 10 and 14 of pregnancy. On Day 10 the uterus appeared similar to that on Day 8, except that the embryos had grown. However, by Day 14 the embryos had begun to resorb.

\section{Antigonadotrophin-reacting antigens on the feto-placental unit}

These experiments were carried out to see whether antigens reacting to the antibodies against LH and hCG are present on the mouse feto-placental unit and, if so, whether these bear any relation to the antifertility effect exercised by the two types of antibodies.

Two techniques were employed to evaluate the reaction of the anti-gonadotrophin antibodies with the frozen sections of uterine horns containing implantation sites: the immunofluorescence technique gave essentially qualitative information, but the method utilizing horseradish peroxidase was amenable to quantitation by measurement of the enzyme activity in conditions in which the reaction products formed over unit time were proportional to the amount of the enzyme fixed with the antibodies on the tissue. With the immunofluorescence method, on Day 6 of gestation there was a slight reaction with anti-LH immunoglobulins, but on Day 12 both immunoglobulin types exhibited intense reactions (Pl. 1, Figs 1-5).

In the horseradish peroxidase test, the antibodies bound to tissue were determined in the second stage of incubation with Protein A conjugated to horseradish peroxidase. On Day 6, the mouse embryos had very few anti-hCG-reacting antigens but greater amounts of anti-LH-reacting material (Text-fig. 2). By Day 12 the amount of reacting antigen was increased to similar levels for both immunoglobulin types.

\section{PLATE 1}

Photographs of tissue of the mouse feto-placental unit stained by the direct immunofluorescence test to detect the presence of antigonadotrophin-reacting antigens.

Fig. 1. Day 6 pregnant mouse treated with anti-hCG Ig.

Fig. 2. Day 6 pregnant mouse treated with anti-oLH Ig.

Fig. 3. Day 12 pregnant mouse treated with anti-hCG Ig.

Fig. 4. Day 12 pregnant mouse treated with anti-oLH Ig.

Fig. 5. Day 12 pregnant mouse treated with control globulins. 
PLATE 1
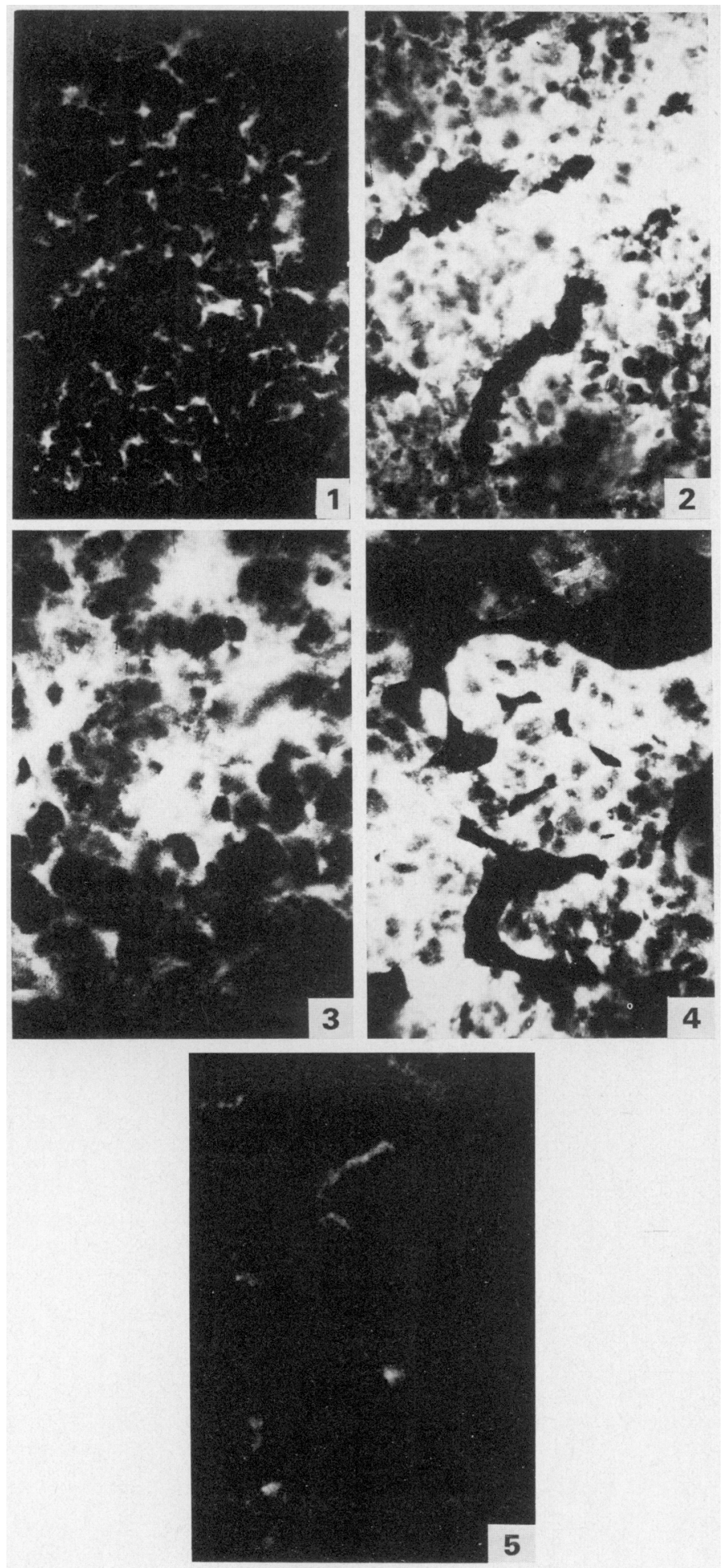


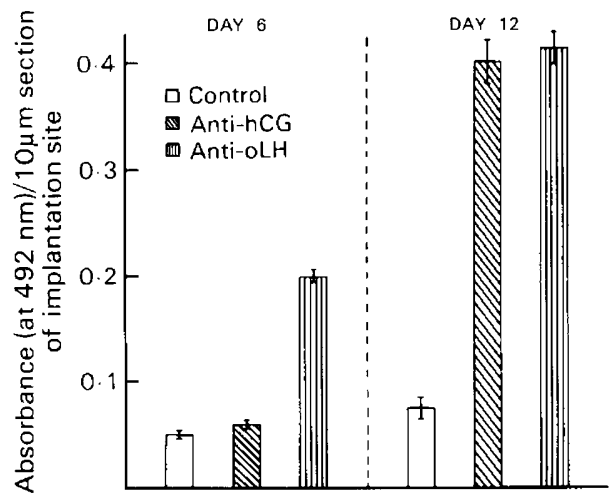

Text-fig. 2. Immunoenzymic quantitation, using horseradish peroxidase conjugated to Protein A, of antigens reacting to anti-ovine LH and anti-hCG immunoglobulins in mouse embryos at Days 6 and 12 of pregnancy. Ten typical sections from a representative mouse were processed as described in the 'Methods'. Values are mean \pm s.d.

\section{Pregnancy rescue by progestational steroids}

It was determined that 3 injections of antibodies to ovine LH on Days 6, 7 and 8 or to hCG on Days 8, 9 and 10 were as effective in terminating pregnancy as 5 injections given on Days 3-7 of pregnancy (Table 3). To evaluate the ability of progestational steroids to overcome the pregnancy terminating action of antigonadotrophins, experiments were performed as indicated in Table 4. Ovariectomy of pregnant mice on Day 6 accompanied by administration of $2 \mathrm{mg}$ MPA en Days 6,9 and 12 sustained the embryonic development and well developed embryos could be seen on Day 16. Administration of immunoglobulins against LH or hCG did not terminate pregnancy under these conditions (Table 4).

Table 3. Effect of immunoglobulins (Ig) against ovine LH and hCG on implantation sites on Day 16 of pregnancy in mice

\begin{tabular}{|c|c|c|c|}
\hline Group & Treatment & $\begin{array}{l}\text { No. of } \\
\text { mice }\end{array}$ & $\begin{array}{c}\text { Implantation sites } \\
\text { on Day } 16 \\
\text { (mean } \pm \text { s.d.) }\end{array}$ \\
\hline I & $\begin{array}{l}\text { Control monkey globulins* } \\
\text { (injected with Freund's } \\
\text { complete adjuvant alone) } \\
(50 \mathrm{mg} / 0 \cdot 5 \mathrm{ml} \text { ) }\end{array}$ & 6 & $6 \cdot 7 \pm 1 \cdot 2$ \\
\hline II & $\begin{array}{l}\text { Monkey anti-oLH Ig* } \\
\quad(47 \mathrm{mg} \mathrm{Ig} / 0.5 \mathrm{ml})\end{array}$ & 8 & $\begin{array}{l}6 \cdot 8 \pm 1 \cdot 7 \\
\text { (resorbed) }\end{array}$ \\
\hline III & $\begin{array}{l}\text { Control monkey globulins } \dagger \\
\text { (injected with Freund's } \\
\text { complete adjuvant alone) } \\
(50 \mathrm{mg} / 0.5 \mathrm{ml})\end{array}$ & 6 & $6 \cdot 3 \pm 1 \cdot 0$ \\
\hline IV & $\begin{array}{l}\text { Monkey anti-hCG Ig } \dagger \\
(45 \mathrm{mg} / 0.5 \mathrm{ml})\end{array}$ & 8 & $\begin{array}{l}6 \cdot 6 \pm 1 \cdot 7 \\
\text { (resorbed) }\end{array}$ \\
\hline
\end{tabular}

Globulins equal to the amount indicated were injected i.p. daily on * Days 6-8; † Days 8-10. 
Table 4. Effect of medroxyprogesterone acetate (MPA) in ovariectomized pregnant mice injected with control globulins or immunoglobulins (Ig) against ovine LH or hCG

\begin{tabular}{|c|c|c|}
\hline Treatment* & $\begin{array}{l}\text { No. of } \\
\text { mice }\end{array}$ & $\begin{array}{l}\text { Implantation sites on } \\
\text { Day } 16 \text { (mean } \pm \text { s.d.) }\end{array}$ \\
\hline None & 4 & $8 \cdot 2 \pm 1 \cdot 6$ \\
\hline Ovariectomy + MPA & 4 & $8.0 \pm 0.8$ \\
\hline $\begin{array}{l}\text { Ovariectomy + MPA } \\
+ \text { anti-oLH Ig on } \\
\text { Days } 6,7 \& 8\end{array}$ & 6 & $7 \cdot 8 \pm 1.6$ \\
\hline $\begin{array}{l}\text { Ovariectomy + MPA } \\
+ \text { control globulins } \\
\text { on Days } 6,7 \& 8\end{array}$ & 6 & $8 \cdot 5 \pm 0.7$ \\
\hline $\begin{array}{l}\text { Ovariectomy + MPA } \\
+ \text { anti-hCG Ig on } \\
\text { Days } 8,9 \& 10\end{array}$ & 6 & $8 \cdot 1 \pm 1 \cdot 6$ \\
\hline $\begin{array}{l}\text { Ovariectomy + MPA } \\
+ \text { control globulins on } \\
\text { Days } 8,9 \& 10\end{array}$ & 6 & $8 \cdot 1 \pm 1 \cdot 6$ \\
\hline
\end{tabular}

* Ovariectomy on Day 6 of pregnancy; 3 i.m. injections of 2 mg MPA each on Days 6, 9 \& 12 of pregnancy.

\section{Discussion}

These experiments demonstrate the sensitivity of the mouse to the abortifacient action of immunoglobulins raised against ovine LH and human CG. Anti-LH immunoglobulins exerted their effect early in pregnancy, at the implantation or peri-implantation stage, whereas the antifertility effect of anti-hCG immunoglobulins was manifested only between Days 10 and 14 of pregnancy. This bears a temporal relation with the period of peak production of an hCG-like material by the mouse placenta. Wide \& Wide (1979) have described the presence in mouse implantation sites of a substance akin to human chorionic gonadotrophin in terms of its physicochemical properties and immunological reactivity. The content of this substance was reported to rise progressively in the post-implantation period, reaching a maximum on Day 11 of pregnancy.

Treatment with anti-ovine $\mathbf{L H}$ or anti-hCG immunoglobulins brought about an equivalent reduction of circulating progesterone concentration. Both antibodies were thus equally effective in preventing the pregnancy-induced rise in progesterone, leading to consideration of whether (1) progesterone is vital for the maintenance of early pregnancy and (2) if antibodies exercise an additional effect on embryonic antigens the target antigens to the two types of antibodies develop at two different times in pregnancy.

Immunofluorescence and immunoenzymic studies demonstrated the presence of antigens reacting to anti-LH and anti-hCG immunoglobulins in the mouse feto-placental unit. The amount of anti ovine LH-reacting material was, however, substantially higher than that reacting to antihCG on Day 6, although the values were similar by Day 12 . These observations suggest that antibodies to gonadotrophins may also act at the feto-placental site.

The reversal of the pregnancy-terminating action of antibodies to ovine $\mathrm{LH}$ and hCG by medroxyprogesterone acetate emphasizes the importance of progestational steroids in the maintenance of pregnancy in mice (Spies \& Quadri, 1967; Madhwa Raj \& Moudgal, 1970; Rao et al., 1972; Munshi et al., 1972; Thau \& Sundaram, 1980; Stevens, 1980; Tandon et al., 1981), probably through its effect on myometrial contractions (Reynolds \& Allen, 1932; Csapo, 1956).

This work was conducted co-operatively with the International Committee for Contraception Research of the Population Council, New York and supported by Research Grants from the 
International Development Research Centre of Canada, the Family Planning Foundation of India, the Rockefeller Foundation, and the Indian Council of Medical Research. We thank Shri Sant Ram, Shri H. K. Sharma and Shri N. K. Bhalla for technical assistance.

\section{References}

Aso, T., Guerreo, R., Cekan, Z. \& Diczfalusy, E. (1975) A rapid 5-hour radioimmunoassay of progesterone and oestradiol in human plasma. Clin. Endocr. 4, 173-182.

Bambra, C.S. \& Gombe, S. (1978) The role of placental gonadotrophins (PMSG and hCG) in pregnancy in the rat. J. Reprod. Fert. 53, 109-115.

Borland, R., Loke, Y.W. \& Wilson, D. (1975) Immunological privilege resulting from endocrine activity of trophoblast in vivo. In Immunology of Trophoblast, pp. 157-169. Eds R. G. Edwards, C. W. S. Howe \& M. H. Johnson. Cambridge University Press.

Csapo, A. (1956) Progesterone "block". Am. J. Anat. 98, 273-291.

Das, C., Salahuddin, M. \& Talwar, G.P. (1976) Investigations on the ability of antisera produced by Pr- $\beta$ hCGTT to neutralize the biological activity of hCG. Contraception 13, 171-181.

Das, C., Talwar, G.P., Ramakrishnan, S., Salahuddin, M., Kumar, S., Hingorani, V., Coutinho, E., Croxatto, H., Hemmingson, E., Johanson, E., Luukainen, T., Shahani, S., Sundaram, K., Nash, H. \& Segal, S.J. (1978) Discriminatory effect of anti Pr- $\beta$ hCG-TT antibodies on the neutralization of the biological activity of placental and pituitary gonadotrophins. Contraception 18, 33-50.

Garner, P.R. \& Armstrong, D.T. (1977) The effect of human chorionic gonadotropin and estradiol-17 $\beta$ on the maintenance of the human corpus luteum of early pregnancy. Am. J. Obstet. Gynec. 128, 469-475.

Hearn, J.P., Short, R.V. \& Lunn, S.F. (1979) The effects of immunizing marmoset monkeys against the $\beta$ subunit of hCG. In Physiological Effect of Immunity Against Reproductive Hormones, pp. 231-249. Eds R. G. Edwards \& M. H. Johnson. Cambridge University Press.

Knobil, E. (1973) On the regulation of the primate corpus luteum. Biol. Reprod. 8, 246-258.

Loewit, K. \& Laurence, K.A. (1969) Termination of pregnancy in the rat with rabbit antibovine $\mathbf{L H}$ serum. Fert. Steril. 20, 679-688.

Madhwa Raj, H.G. \& Moudgal, N.R. (1970) Hormonal control of gestation in the intact rat. Endocrinology 86, 874-889.

Midgley, A.R., Jr \& Pierce, G.B. (1962) Immunohistochemical localization of human chorionic gonadotropin. J. Exp. Med. 115, 289-294.

Moudgal, N.R., Mukku, V.R., Prahalada, S., Murty, G.S. \& Li, C.H. (1978) Passive immunization with an antibody to the $\beta$-subunit of ovine luteinizing hormone as a method of early abortion: a feasibility study in monkeys (Macaca radiata). Fert. Steril. 30, 223-229.

Munshi, S.R., Purandare, T.V. \& Rao, S.S. (1972) Effect of antiserum to ovine luteinizing hormone on corpus luteum function in mice. J. Reprod. Fert. 30, 7-12.

Paul, S., Jailkhani, B.L., Gupta, P.D. \& Talwar, G.P.
(1979) Isolation, functional maintenance and properties of human placental syncytiotrophoblasts. In Recent Advances in Reproduction and Regulation of Fertility, pp. 375-385. Ed. G. P. Talwar. Elsevier/ North-Holland Biomedical Press, Amsterdam.

Prahalada, S., Mukku, V.R., Rao, A.J. \& Moudgal, N.R. (1975) Termination of pregnancy in Macaques (Macaca radiata) using monkey antiserum to ovine luteinizing hormone. Contraception 12, 137-147.

Rao, A.J., Madhwa Raj, H.G. \& Moudgal, N.R. (1972) Effect of LH, FSH and their antisera on gestation in the hamster (Mesocricetus auratus). J. Reprod. Fert. 29, 239249.

Reynolds, S.R.M. \& Allen, W.M. (1932) The effect of progestin containing extracts of corpora lutea on uterine mobility in the unanesthetized rabbit with observations on pseudopregnancy. Am. J. Physiol. 102, 39-55

Rice, B.F., Hammerstein, J. \& Savard, J. (1964) Steroid hormone formation in the human ovary: action of gonadotrophins in vitro in the corpus luteum. J. Clin. Endocr. Metab. 24, 606-615.

Shastri, N., Dubey, S.K., Vijaya Raghavan, S., Salahuddin, M. \& Talwar, G.P. (1978) Differential affinity of anti Pr- $\beta$-hCG-TT antibodies for hCG and hLH. Contraception 18, 23-34.

Spies, H.G. \& Quadri, S.K. (1967) Regression of corpus luteum and interruption of pregnancy in rabbits following treatment with rabbit serum to ovine $\mathrm{LH}$. Endocrinology 80, 1127-1132.

Stevens, V.C. (1976) Perspectives of development of a fertility control vaccine from hormonal antigens of the trophoblast. In Development of Vaccines for Fertility Regulation, pp. 93-110. Scriptor, Copenhagen.

Stevens, V.C. (1980) The current status of anti-pregnancy vaccines based on synthetic fractions of hCG. In Immunological Aspects of Reproduction and Fertility Control, pp. 203-216. Ed. J. P. Hearn. MTP Press Ltd. London.

Tandon, A., Das, C., Jailkhani, B.L. \& Talwar, G.P. (1981) Efficacy of antibodies generated by $\mathrm{Pr}-\beta$ hCG-TT to terminate pregnancy in baboons: its reversibility and rescue by medroxyprogesterone acetate. Contraception 24, 83-95.

Thau, R. \& Sundaram, K. (1980) The mechanism of action of antifertility vaccine in the rhesus monkey: reversal of the effects of antisera to the $\beta$-subunit of ovine luteinizing hormone by medroxyprogesterone acetate. Fert. Steril. 33, 317-320.

Wide, L. \& Wide, M. (1979) Chorionic gonadotrophin in the mouse from implantation to term. J. Reprod. Fert. 57, 5-9.

Yoshimi, T., Strott, C.A., Marshall, J.R. \& Lipsett, M.B. (1969) Corpus luteum function in early pregnancy. $J$. clin. Endocr. Metab. 29, 225-230. 